Challenges and Successes on the Path toward a Solar-Powered Community
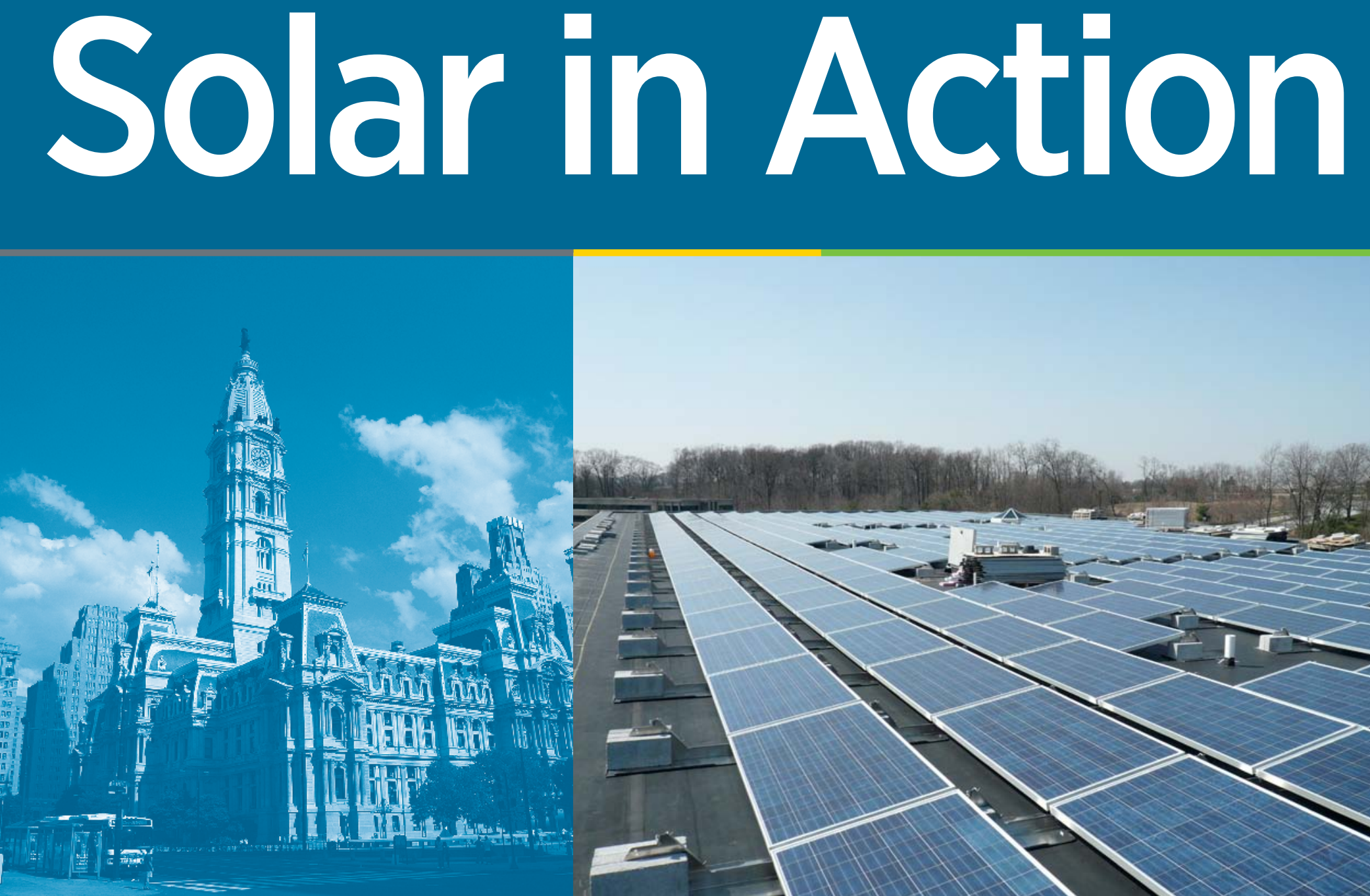

SOLAR AMERICA CITIES

Part of the Solar America Communities program

October 2011

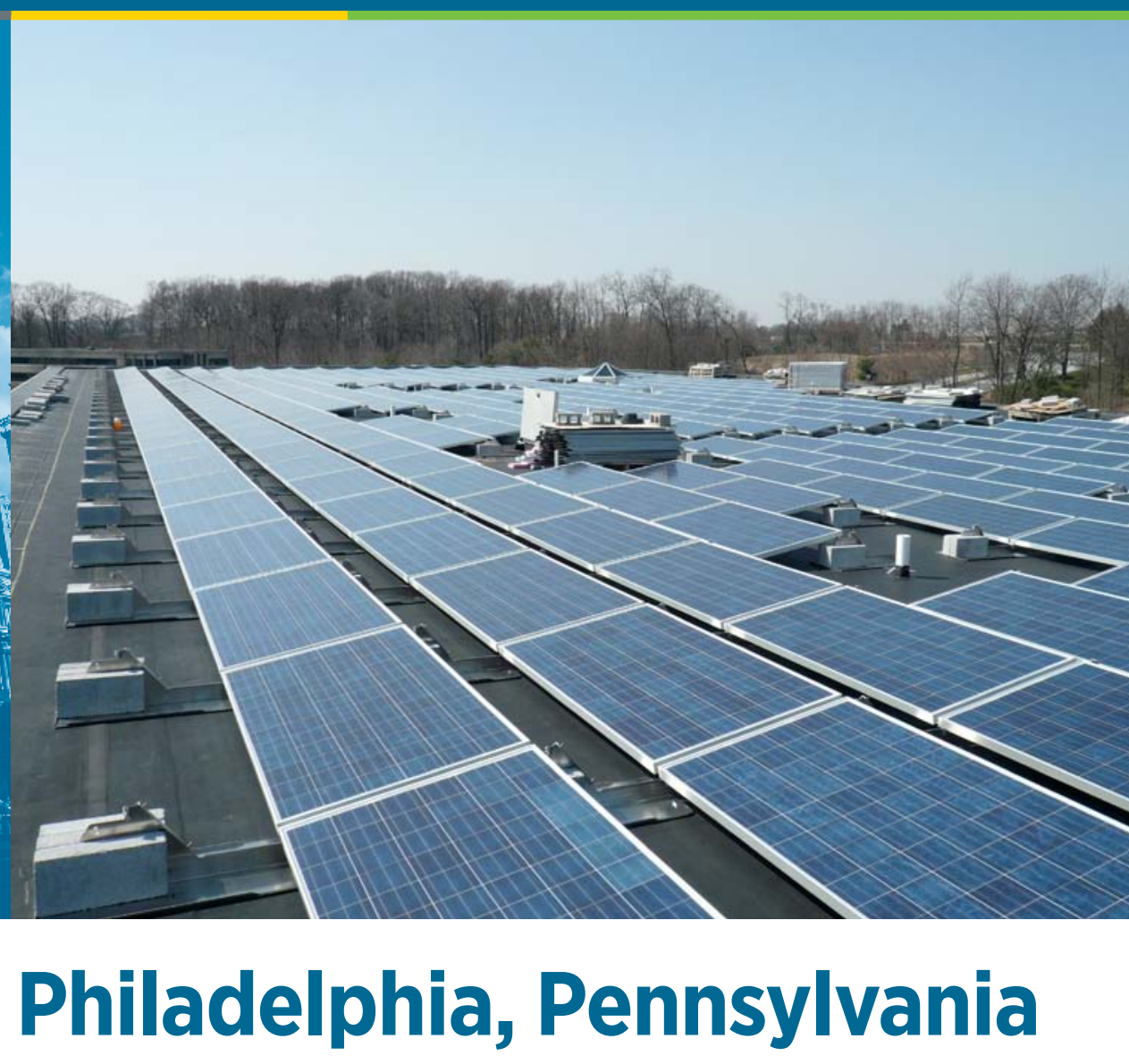

Includes case studies on:

- Large-Scale Municipal PV Installations

- Philadelphia Solar Installation Guidebook for Developers

- Solar Tutorial Videos for Homeowners 

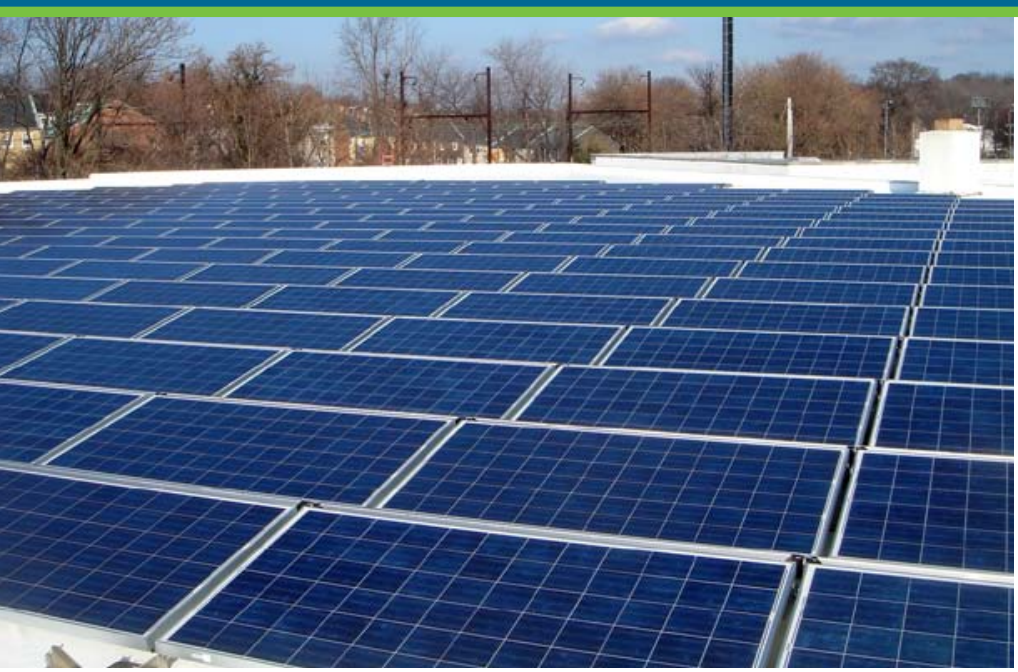

The Bushnell Company in the Germantown neighborhood of Philadelphia uses an 85-kW rooftop PV installation. Photo from Mercury Solar Solutions, NREL/PIX 18064

- AE Polysilicon Corporation

- University of Pennsylvania

- Princeton University

\section{Cost-Sharing Partners}

- City of Philadelphia

- The Reinvestment Fund

- Skanska

- Conergy

- Ben Franklin Technology Partners

- Villanova University

- Philadelphia University

- AKF Engineers

- Clean Power Markets, Inc.

- Philadelphia Water Department.

The Solar Cities team developed a plan to help Philadelphia generate 2.3 MW of solar electricity by 2011 and 57.8 MW by 2021, the city's proportional share of the Commonwealth of Pennsylvania's Alternative Energy Portfolio Standard.

\section{Accomplishments and Highlights}

- Initiated planning and development of large-scale PV projects on municipal facilities

- Developed and adopted a solar implementation plan that is replicable and fully integrated with updated citywide plans and institutional processes for guiding decisions on land use, economic development, and infrastructure investment

- Established the energy portion of Greenworks Philadelphia, a 6-year plan to help make Philadelphia the greenest city in America

- Published the Philadelphia Solar Installation Guidebook for developers

- Produced Web-based information to educate residents and small commercial businesses about solar, including five Solar Tutorial videos; a Virtual Solar Tour, which is continually updated to include new solar installations; and a Web version of the Philadelphia Solar Installation Guidebook. This information can be found at the Mayor's Office of Sustainability website: www.phila.gov/ green/solar.html.

\section{Case Studies: Successes and Challenges}

\section{Large-Scale Municipal PV Installations}

As the cost of energy produced from fossil fuel rises while the price of solar technology drops, Philadelphia is encouraging residents and businesses to install solar panels and is in the process of installing a number of large-scale solar arrays on city-owned land. The city is collaborating on plans for three large-scale solar installations, which together will provide enough electricity to power more than 600 homes. Philadelphia and its partners strategically considered many sites for these installations before choosing the Navy Yard, the Philadelphia Water Department's (PWD) wastewater pollution control plant, and PWD's Baxter water treatment facility.

The PWD installed a 250-kW PV installation at the Southeast Wastewater Pollution Control Plant. The project was the City of Philadelphia's first municipally owned solar installation. The system is ground-mounted and covers more than an acre of currently unused land. The treatment plant will use all of the solar power generated onsite. PWD will own the Solar Renewable Energy Credits. Colloid Environmental Technologies Company, selected through the public works bid process, installed the project. 
The project was made possible by $\$ 850,000$ from the city's Energy Efficiency and Conservation Block Grant from DOE, leveraged PWD funds, and technical assistance from DOE's Solar America Cities program.

PWD also is looking to locate a multi-megawatt solar installation at a facility through a Power Purchase Agreement. The department designated two other facilities as possible locations as a result of site feasibility studies executed with the technical assistance team at the National Renewable Energy Laboratory. These projects would decrease the amount of electricity that PWD would need to purchase from PECO (the local utility) and would provide the facilities with clean, emissions-free energy at a stable price over the life of the solar panels (more than 20 years).

The Philadelphia Industrial Development Corporation is working with Conergy and Exelon on the development of a 1.3-MW PV system at the Philadelphia Navy Yard. The PV project is being developed on a 7-acre brownfield site (potentially contaminated land) and is the subject of a U.S. Environmental Protection Agency case study (see the website link in the Additional Resources section).

\section{Philadelphia Solar Installation Guidebook for Developers}

The Philadelphia Solar Installation Guidebook is designed for developers of both residential and commercial PV energy systems. It addresses procedures for planning, siting, permitting, installing, interconnecting, and net metering solar installations. The city was cognizant that the requirements for installing PV could be difficult to understand not only for residential owners but by professional contractors as well. The guide provides a starting point for understanding the pros and cons of an installation, and it leads the reader through the complete process of paying for, permitting, installing, and interconnecting a PV system. The guide represents a collaborative effort among multiple partners including:

- Celentano Energy Services

- Governor Ed Rendell's Solar Working Group

- Mayor's Office of Transportation and Utilities

- PECO

- Pennsylvania Department of Environmental Protection

- Philadelphia's Department of Licenses and Inspections

- Philadelphia's Mayor's Office of Sustainability

- Pennsylvania Solar Energy Industries Association

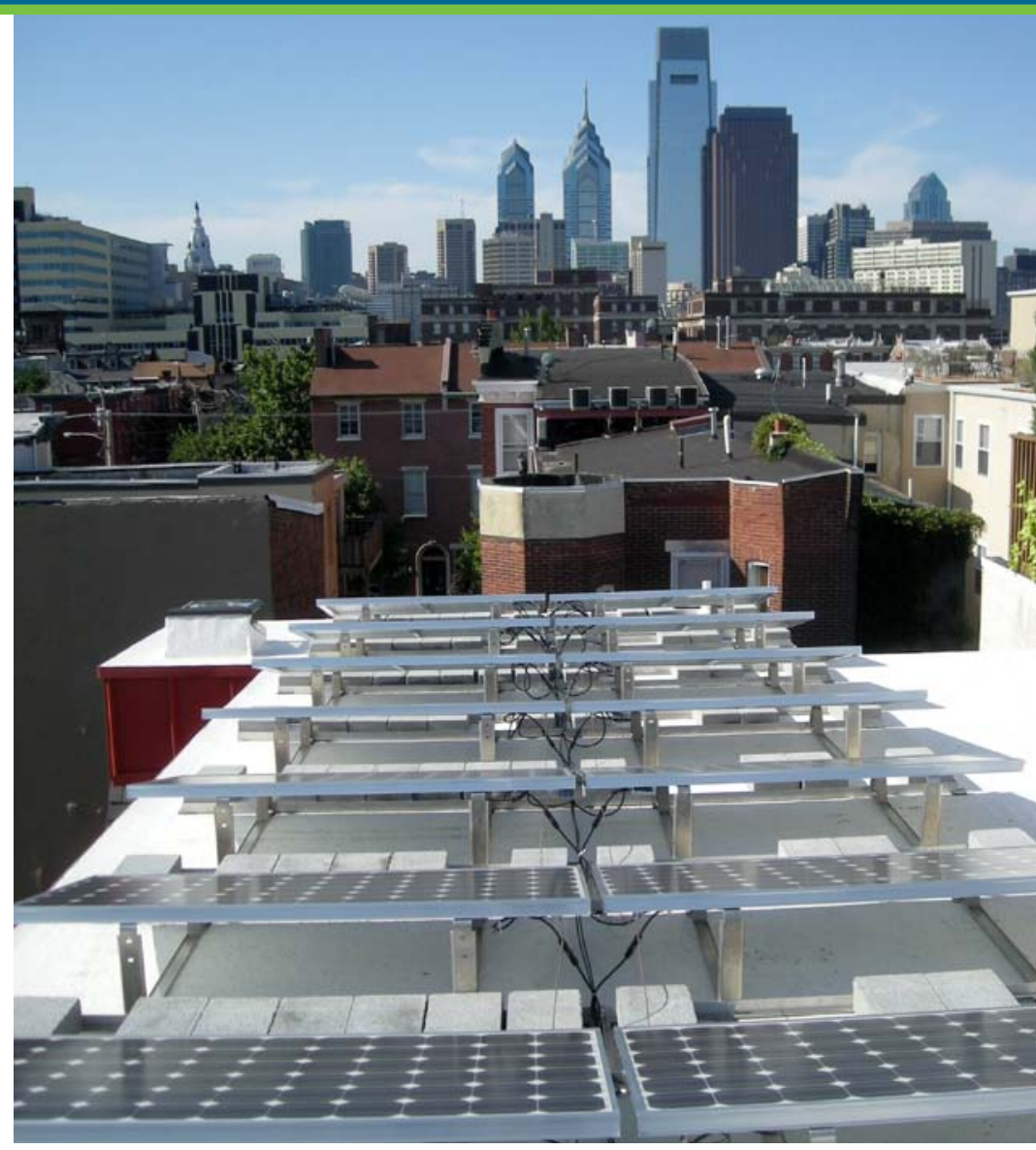

The Philadelphia skyline is a beautiful backdrop to a 3-kW PV rooftop installation in the Center City District. Photo from Mercury Solar Solutions, NREL/PIX 18063

- Philadelphia's Solar Partnership Advisory Board

- Philadelphia Zoning Code Commission

The guidebook is intended to serve as a reference for potential project developers (land/property owners, financiers) and contractors who are considering pursuing PV projects within the City of Philadelphia. It answers many of the questions that these individuals will encounter along the way including:

- Who can install a PV system within the City of Philadelphia?

- What should I consider before installing a PV system?

- What permits will be required and when?

- Who do I need to contact before installing a system?

- What incentives are available for PV systems?

The guidebook is organized into the following sections:

- Solar Basics

- System Design Considerations (technical and design aspects of PV system installation)

- Process Overview (codes, permitting, and utility requirements)

- Incentives and Benefits 
Additionally, a list of Frequently Asked Questions is included as an appendix that installers and developers may find helpful and are encouraged to review.

The guidebook supports the city's commitment to ensuring that safe, reliable, and well-designed PV systems are installed on as many homes and businesses as possible as a means of creating a sustainable city for all Philadelphians to enjoy.

\section{Solar Tutorial Videos for Homeowners}

Philadelphia produced a five-part Web series aimed at educating the Greater Philadelphia area on the topic of residential solar installations and increasing home energy efficiency throughout the region. The production team worked closely with experts in the energy field to produce informational videos that provide complex information in an organized and entertaining fashion. The first solar tutorial video explains the basic concepts involved with PV systems. Specifically, this video discusses how a PV array works, homeowners' relationship to the electrical grid when they install solar, and why the Philadelphia area is a great place for solar technology.

In the second tutorial, viewers learn how to prepare their homes for solar by making it more energy efficient. Step-by-step instructions on how to use the online Energy Star guide to make a house more energy efficient are provided. Information on the Philadelphia Solar Installation Guidebook also is included. Finally, viewers learn how to assess their home on whether solar is an appropriate option.

In the third tutorial, viewers learn how solar $\mathrm{PV}$ is an economical and environmentfriendly means of powering a home. A detailed discussion of the future of renewable energy within Pennsylvania and the potential financial savings that will follow for homeowners is included.

The fourth tutorial provides a comprehensive overview of how to finance a residential PV installation. It covers federal tax credits, state grants, money gained by selling alternative energy credits, and more.

In the fifth tutorial, viewers learn what to look for when selecting a solar PV installer. Criteria include qualifications an installer should have and what information the installer should cover with homeowners. An overview of the solar PV installation process also is provided.

\section{Top Takeaways}

- Taking ownership of a solar project by a city is a positive experience, and Philadelphia is proud of the $250-\mathrm{kW}$ PV installation at the Philadelphia Water Department. However, the economics of the project have the potential to shine even more with a Power Purchase Agreement and when other funding can be leveraged.

- Administering solar renewable energy credits has proven to be beneficial because the city's approach to electricity purchasing enables Philadelphia to use them to fulfill compliance obligations to suppliers.

- The Philadelphia Solar Installation Guidebook has been a very useful tool and has received positive feedback from developers.

- While creating the guidebook, Philadelphia found that it was important to look for language in existing codes and bylaws in addition to existing guides published by city agencies.

- Support from the state is extremely useful. For example, a strong renewable portfolio standard (e.g., the Alternative Energy Portfolio Standard in Pennsylvania) can drive solar installations.

- "Behind the meter" projects, or smaller projects in which the energy produced is used to primarily offset the load of the facility or residence, are having more success due to the economics and the simpler interconnection process.

- Local incentives help send the right message. Philadelphia has been able to use funds through the federal competitive Energy Efficiency and Conservation Block Grant to provide low-interest solar financing, but that funding is limited.

\section{Next Steps}

On June 17, 2010, Philadelphia's City Council unanimously approved creating the Philadelphia Energy Authority to help city government understand the coming deregulation of Pennsylvania's electricity markets. The Philadelphia Energy Authority will be able to form Power Purchase Agreements 
for longer terms than may be allowed under the city charter, which prohibits contracts longer than four years. The Philadelphia Energy Authority can also help develop projects, such as biogas generation systems using the methane released by the Water Department's treatment facilities, or solar plants at city government facilities.

The city also has the following plans underway:

- Create an appendix on solar hot water for the installation guidebook

- Continually update website content, including the solar guidebook and the virtual solar tour as more projects are installed or are slated for installation

- Create a map that accounts for various factors related to solar, including building height for shading, levels or interconnection difficulty, rooftop and vacant land availability, and zoning characteristics. These overlays will determine which areas of the city are prime for solar and push pilot legislation that supports solar development in those areas.

\section{Additional Resources}

- Philadelphia Mayor's Office of Sustainability: www.phila.gov/green/

- Philadelphia Solar Installation Guidebook: www.phila.gov/green/PDFs/PhillySolarGuidebook.pdf

- Philadelphia Navy Yard Solar Project: www.epa.gov/ renewableenergyland/docs/success_navyyard_pa.pdf 
Ann Arbor Austin Berkeley Boston Denver Houston Knoxville Madison Milwaukee Minneapolis-Saint Paul New Orleans New York Orlando Philadelphia Pittsburgh Portland Sacramento Salt Lake City San Antonio San Diego San Francisco San José Santa Rosa Seattle Tucson
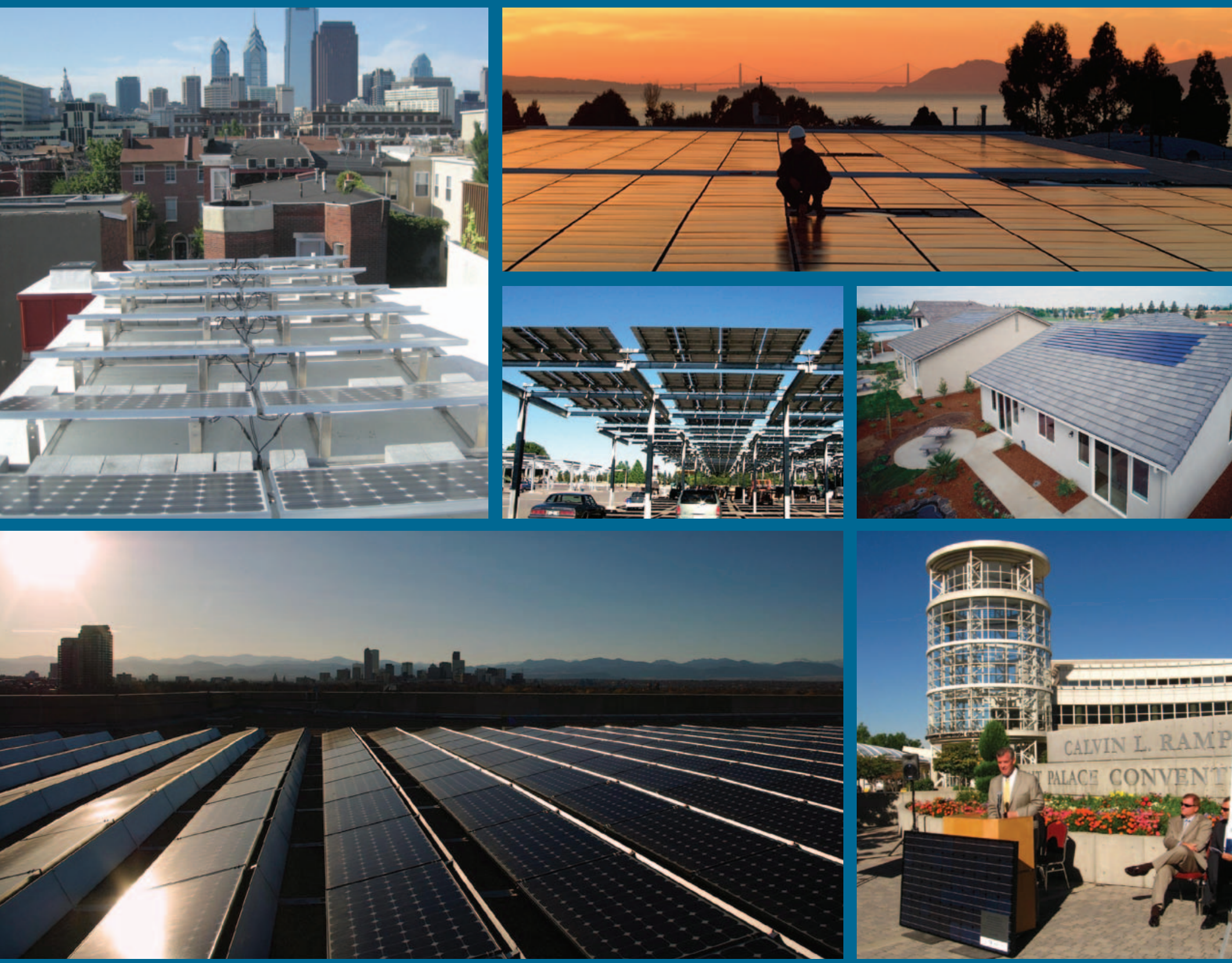

Clockwise from top left: Photovoltaic system in Philadelphia Center City district (photo from Mercury Solar Solutions); rooftop solar electric system at sunset (photo from SunPower, NREL/PIX 15279); Premier Homes development with building-integrated PV roofing, near Sacramento (photo from Premier Homes, NREL/PIX 15610); PV on Calvin L. Rampton Salt Palace Convention Center in Salt Lake City (photo from Utah Clean Energy); PV on the Denver Museum of Nature and Science (photo from Denver Museum of Nature \& Science); and solar parking structure system at the Cal Expo in Sacramento, California (photo from Kyocera Solar, NREL/PIX 09435)

\section{a ENERCY}

Energy Efficiency \& Renewable Energy
EERE Information Center

1-877-EERE-INFO (1-877-337-3463)

www.eere.energy.gov/informationcenter

Printed with a renewable-source ink on paper containing at least $50 \%$ wastepaper, including $10 \%$ post consumer waste.
Prepared by the National Renewable Energy Laboratory (NREL) NREL is a national laboratory of the U.S. Department of Energy Office of Energy Efficiency and Renewable Energy Operated by the Alliance for Sustainable Energy, LLC

DOE/GO-102011-3255 • October 2011 